\title{
ФIНАНСИ
}

\section{ТА ІНВЕСТИЦІї}

УдК 339.727.2 DOI: https://doi.org/10.31617/zt.knute.2019(107)08

\begin{tabular}{|c|c|}
\hline ДЗЮБА Павло & $\begin{array}{l}\text { Д. е. н., доцент, доцент кафедри міжнародних фінансів } \\
\text { Інституту міжнародних відносин Київського }\end{array}$ \\
\hline $\begin{array}{l}\text { E-mail: pavlo.dziuba@gmail.com } \\
\text { ORCID: 0000-0003-2932-0908 }\end{array}$ & $\begin{array}{l}\text { національного університету імені Тараса Шевченка } \\
\text { вул. Юрія Іллєнка, 36/1, м. Київ, 04119, Україна }\end{array}$ \\
\hline
\end{tabular}

\section{БІГЕВІОРИЗМ: ЕВОЛЮЦІЯ ТА МІСЦЕ В ТЕОРІЇ МІЖНАРОДНОГО ПОРТФЕЛЬНОГО ІНВЕСТУВАННЯ}

Доведено окремий статус бігевіоризму в сучасній теорії міжнародного портфельного інвестування, який не є самодостатнім в епістемологічному сенсі, а лише коригує рішення портфельних інвесторів за портфельною та вартісною парадигмами міжнародного інвестування. Обтрунтовано схильність до інвестування на місцевих ринках як одного з найпоширеніших відхилень рішень міжнародних портфельних інвесторів та чинника, щзо перешкоджає міжнародному рухові портфельних інвестииій.

Ключові слова: поведінкова теорія, міжнародне портфельне інвестування, схильність до інвестування на місцевих ринках, теорія перспектив, теорія поведінкового портфельного менеджменту.

Дзюба П. Бихевиоризм: эволюция и место в теории межљдународного портфельного инвестирования. Доказан отдельный статус бихевиоризма в современной теории международного портфельного инвестирования, который не является самодостаточным в эпистемологическом смысле, а лишь корректирует решения портфельных инвесторов согласно портфельной и стоимостной парадигмам международного инвестирования. Обоснована склонность к инвестированию на локальных рынках как одного из наиболее распространенных поведенческих отклонений решений международных портфельных инвесторов и фактора, препятствующего международному движению портфельных инвестиций.

Ключевые слова: поведенческая теория, международное портфельное инвестирование, склонность к инвестированию на локальных рынках, теория перспектив, теория поведенческого портфельного менеджмента.

(C) Дзюба П., 2019 
Постановка проблеми. Сучасна теорія міжнародного портфельного інвестування пройшла тривалий шлях розвитку, численні трансформації та удосконалення, розширення й поглиблення. І хоча здебільшого вона розвивалася еволюційно, спостерігалася принаймні одна наукова революція, що ознаменувала появу нової - портфельної - парадигми, яка стала домінувати. Сьогодні ця теорія має складну гносеологічну структуру, розвивається на біпарадигмальній основі, дедалі яскравіше демонструє мультидисциплінарний характер. Традиційні погляди на процес міжнародного портфельного інвестування базуються на раціональному характері поведінки індивідів-інвесторів, проте на практиці таке припущення часто не підтверджується. Поведінкові теорії, які значною мірою формують мультидисциплінарність науки міжнародного портфельного інвестування, опонують концепції раціональності, розглядають ірраціональні рішення інвесторів, фокусуються на окремих специфічних поведінкових відхиленнях інвестиційних рішень, мають високий ступінь емпіричної перевірки. Бігевіористські теорії у багатьох випадках є валіднішими порівняно з традиційними, оскільки мають значно менше припущень, а самі припущення є реалістичнішими.

Отже, важливим у теоретично-методологічному плані та актуальним щодо розвитку науки є дослідження основних положень цих теорій з метою ідентифікації їх місця в системі знання з міжнародного портфельного інвестування, визначення їх гносеологічного статусу та основних напрямів взаємозв'язку з іншими складниками теорії. Практична актуальність цього завдання зумовлена наявністю низки поведінкових парадоксів, пов'язаних з міжнародними інвестиційними рішеннями та які неможливо пояснити в рамках методології традиційних теорій.

Аналіз останніх досліджень і публікацій. Наукові дослідження та публікації у сфері міжнародного портфельного інвестування сконцентровані історично в рамках двох великих тематичних кластерів, які представляють дві наявні у цій галузі парадигми. Так, ключові етапи еволюції портфельної парадигми міжнародного інвестування формувалися у наукових розробках таких відомих учених, як Г. Марковіц, А. Рой, В. Шарп, Р. Мертон, Б. Солнік, Ф. Лонджин, Б. Ром, К. Фергюсон, Дж. Чен, М. Тодоні, Ч. Еун і Б. Резнік, С. Макдоуел, Дж. Флетчер [1-14] та ін. Науковцями сформовано три основні етапи розвитку портфельної парадигми: теорія портфеля, теорія ринку капіталу та постсучасна теорія портфеля, а також визначено п'ять іiї основних концепцій: ефективного портфеля; диверсифікації; оптимізації; міжнародної диверсифікації та оцінювання дохідностей. Традиційна вартісна парадигма міжнародного інвестування сформувалася та розвивалася під впливом наукових досліджень Б. Грема та Д. Додда [15], Я. Тінбергена [16], Ю. Фами й К. Френча [17-21], М. Ганауера та М. Лінгарта [22], Н. Сакісі, Ф. Фабоцці та С. Тана [23], С. Еснесса і Т. Московіца [24] та ін. Зазначені парадигми мають у своїй основі принципово відмінні моделі постановки наукових проблем та їхнє розв'язання. Поява ж поведінкових 
теорій, приміром, викладених у працях Г. Шефріна та М. Стетмена [25], Т. Говарда [26; 27] та ін., поставила на порядок денний питання про їх науковий статус і місце в наявній системі знань. Так, поведінкову портфельну теорію Т. Говарда називають іноді новою парадигмою, що наразі не знайшло підтвердження в науковій літературі, а питання іiі епістемологічної ідентифікації залишається невирішеним.

3-поміж останніх досліджень поведінкового напряму доцільно відзначити праці Дж. Бі, Г. Джина та К. Менга [28], Й. Лоу [29]. Проте емпіричний напрям розвитку бігевіоризму в частині прийняття інвестиційних рішень міжнародними інвесторами сконцентрований переважно у сфері дослідження такого визначального поведінкового відхилення, як схильність до інвестування на місцевих ринках, зокрема в дослідженнях А. Оелера, Ш. Уендта та М. Горна [30], Р. Макгерже, С. Пола й С. Шанкара [31], М. Гераніо та В. Лаззарі [32] та ін.

Метою статті $\epsilon$ визначення місця поведінкової портфельної теорії у сучасній системі знань з міжнародного портфельного інвестування, ідентифікація основних напрямів її взаємозв'язку з іншими складниками наявного знання на основі дослідження ії основних сутнісних рис і недоліків.

Матеріали та методи, що використано в дослідженні, охоплюють загальнонаукові методи пізнання - аналіз і синтез, абстрагування, історичний та системний підхід; а також специфічні, зокрема логічне та графічне моделювання. Дослідження проведено на основі праць провідних учених у сфері фінансової теорії та міжнародного портфельного інвестування, бігевіоризму.

Результати дослідження. Поведінкові теорії завжди протиставляли своє бачення рішень індивідів раціональній основі, і це стосується не лише міжнародного портфельного інвестування, а й інших сфер. Попри те, що окремі поведінкові аспекти рішень щодо портфельного інвестування можна виділити в рамках теорії ігор, основоположним дослідженням у цій сфері прийнято вважати працю Д. Канемана та А. Тверскі «Теорія перспектив: аналіз рішень в умовах ризику» (1979 р.) [33]. Теорія Канемана і Тверскі опонує не буквально портфельній оптимізації на основі корисності, а теорії корисності у принципі, протиставляючи їй поведінкову теорію перспектив. Згідно 3 нею у процесі прийняття рішень в умовах ризику спостерігають два важливі поведінкові ефекти: ігнорування та визначеності. Перший означає, що індивіди зазвичай відхиляють альтернативи, що передбачені всіма можливими варіантами розвитку (перспективами). Цей ефект призводить до нестабільності рішень за умов різного формату представлення передбачуваного вибору. Другий ефект свідчить, що індивіди недооцінюють єдино можливі перспективи порівняно з тими, що досягаються лише з певною імовірністю. Така поведінка спричиняє зниження схильності до ризику в перспективах із напевно можливими прибутками та зростання цієї схильності у перспективах із напевно можливими збитками. Втім, функція вартості 
прибутків та/або збитків є опуклою донизу для позитивного діапазону незалежної змінної та опуклою догори для негативних значень останньої. Тож ступінь опуклості є вищим у другому випадку.

Ще однією гносеологічно значущою поведінковою теорією прийняття рішень в умовах невизначеності є так звана теорія $S P / A$, розроблена у 1987 р. Л. Лопес [34]. Назва цієї теорії походить від таких важливих психологічних аспектів і відчуттів індивіда, як безпека $(S)$, потенціал $(P)$ та прагнення $(A)^{1}$. Тлумачення безпеки у Лопес збігається з іiі баченням у рамках підходу максимальної визначеності, а саме уникнення низького рівня кінцевого багатства. Схоже бачення стосується й прагнення: за підходом максимальної визначеності, тобто мінімальна прийнятна дохідність $M A R^{2}$. Потенціал має досягнути високого рівня кінцевого багатства.

За теорією $S P / A$, бажання агентів приймати ризик залежить від двох емоцій: страху та надії. Формалізовано їхній вплив визначається як відповідні ваги-частки до дизкумулятивних ймовірностей. Для визначення очікуваного багатства Лопес використовує просту формулу:

$$
E(W)=\sum p_{i} W_{i}
$$

де $E(W)$ - очікуване багатство;

$p_{i}-$ ймовірність отримання $i$-го рівня багатства;

$W_{i}-i-\check{u}$ рівень багатства.

Формулу (1) можна представити у форматі дизкумулятивних ймовірностей:

$$
E(W)=\sum D_{i}\left(W_{i}-W_{i-1}\right)
$$

де $W_{1} \leq W_{2} \leq \ldots \leq W_{n}$;

$W_{0}=0$

$i=1,2 \ldots n$;

$D_{i}$ - дизкумулятивна ймовірність реалізації певного рівня багатства.

Дизкумулятивна ймовірність є оберненою до кумулятивної. Вона означає, що рівень багатства $W_{1}$ буде отриманий напевно: ймовірність $100 \%\left(D_{1}=1\right)$. Рівень багатства $W_{2}-W_{1}$ буде отримано $з$ ймовірністю $D_{2}$ і т. д.

За теорією $S P / A$, емоція страху інкорпорована до завищення часток ймовірностей гірших результатів порівняно з кращими. Такі індивіди оцінюють майбутнє багатство песимістично. Емоція надії передбачає надзвичайно оптимістичне оцінювання майбутнього багатства - індивіди завищують частки ймовірностей кращих результатів порівняно $з$ гіршими. У термінах моделі надія - це потенціал, а страх - це безпека. Зрештою, ці емоції зумовлюють вибір кожного індивіда, формуючи дизкумулятивну функцію. Вибір слід робити так, аби збалансувати вплив обох емоцій.

\footnotetext{
${ }^{1}$ Від англ. security, potential та aspiration відповідно.

2 Від англ. minimum acceptable return - мінімальна прийнятна дохідність.
} 
Поведінкову теорію в контексті портфельного вибору сформульовано у 2000 р. в дослідженні Г. Шефріна та М. Стетмена «Поведінкова теорія портфеля» [25]. Як зазначають самі автори, їхня теорія базується на двох попередніх - теорії $S P / A$ і теорії перспектив. При цьому з теорії перспектив вони запозичили ідею так званого множинного ментального обліку ${ }^{3}$. Відповідно розроблено дві версії поведінкової теорії портфеля: на основі одиничного ментального обліку (модель $S A$ ) та на основі множинного ментального обліку (модель $M A)$.

$M о д е л ь ~ S A$ передбачає, що всі інвестори розглядають портфель як цілісність, тобто керуються підходом одиничного ментального обліку. Цей підхід багато в чому збігається з постулатами теорії портфеля [25, с. 133], зокрема стосовно сприйняття інвесторами коваріацій. Оскільки традиційна ефективна множинність генерується у системі координат «ризик очікувана дохідність», то за $S A$-моделлю незалежною змінною виступає ймовірність того, що кінцеве багатство буде меншим від бажаного рівня - $\operatorname{Prob}(W \leq A)$. Залежною змінною виступатиме очікуваний рівень багатства $E(W)$ в умовах трансформації дизкумулятивної функції внаслідок впливу емоцій, досліджених у моделі $S P / A,-\left(E_{h}(W)\right.$. Техніка генерування множинності залишається незмінною. До того ж ефективні поведінкові портфелі переважно не є ефективними як за традиційним підходом ${ }^{4}$, так і за теоремою структури портфеля.

На відміну від підходу на основі корисності, який ураховує лише ризик, дохідність і схильність до ризику, оптимальний поведінковий портфель формується 3 урахуванням п'яти факторів. Ці фактори охоплюють власне ступінь страху та надії, а також ступінь прагнення та два спеціальні відносні показники, що характеризують силу страху щодо надії та силу прагнення щодо надії та страху.

Модель $M A$ передбачає, що інвестори розглядають портфель не як цілісність, а як дизагреговані інвестиції, та не зважають на коваріації між різними частинами цих інвестицій. Ця модель виходить 3 того, що здебільшого інвестори мають не лише високий чи лише низький рівень прагнення, а в ментальному плані поєднують обидва. Портфелі таких індивідів обліковуються у їхній свідомості як кілька умовних пірамідальних прошарків, що слугують різним цілям, приміром, уникнення втрат, отримання прибутків тощо [25, с. 141]. Ці прошарки і представляють окремі ментальні рахунки інвесторів.

\footnotetext{
${ }^{3}$ Multiple mental accounting.

${ }^{4}$ Інші емпіричні дослідження, навпаки, засвідчують ефективність поведінкових портфелів у традиційному розумінні. Приміром, дослідження М. Пфіффельманн, Т. Роджера та О. Бурачнікової показує, що в умовах відсутності будь-яких обмежень 70 \% ефективних поведінкових портфелів, сформованих за моделлю Шефріна-Стетмена, будуть ефективними за Марковіцем [35]. При цьому ефективні поведінкові портфелі геометрично розташовані у правій верхній частині ефективної множинності Марковіца, що характеризує їх високий ризик. У практичній площині це означає, що навіть коли ефективні поведінкові портфелі $є$ ефективними у традиційному сенсі, вони не будуть обрані як оптимальні пересічними інвесторами, оскільки такий вибір має передбачати високий ступінь схильності до ризику.
} 
Модель Шефріна-Стетмена розглядає два ментальні рахунки для високого та низького рівня прагнення. Загалом вона відповідає сучасній практиці інвестиційного менеджменту: різні субпортфелі управляються різними менеджерами, над якими стоїть лідменеджер. У цій моделі два ментальні рахунки - це два різні субпортфелі. Початковий рівень багатства розподілений між двома рахунками, проте, оскільки загальна ідея моделі базується на принципі максимальної визначеності, то перша одиниця початкового багатства буде розподілена на користь рахунку 3 низьким прагненням. Оскільки кожен рахунок управлятиметься з урахуванням окремих інвестиційних цілей, цілком можливі протилежні позиції у рамках цих рахунків, що на рівні всього портфеля можуть приводити до взаємної компенсації.

Розглянута теорія має одну важливу рису: вона доволі добре пояснює окремі рішення портфельних інвесторів, що базуються на особливостях їхньої поведінки та емоціях, проте не дає чітких рекомендацій щодо портфельного вибору. Конкретні управлінські рішення мають прийматися на засадах цієї теорії самими менеджерами. Ідею множинного ментального обліку широко використовують у сучасному інституційному менеджменті, а саме розведення управління окремими субпортфелями за класами активів.

Існують й численні емпіричні приклади неефективності портфельного менеджменту на основі поведінкових підходів, проте його важлива гносеологічна особливість в тому, що він пов'язаний з принципом максимальної визначеності, зокрема з критеріями Роя, Телсера, Катаоки та $V a R$-підходом. Із практичної точки зору, поведінкова теорія ШефрінаСтетмена $є$ позитивною - вона спрямована на забезпечення контролю над ризиком та потенційними втратами, а також ураховує реальні аспекти людської ментальності.

Приклади неефективності поведінкових портфелів надано М. Бестом та Р. Грауером [36]. Досліджено портфелі, що сформовані за теорією перспектив, за двох умов: існування можливостей вільно брати та надавати кошти в позику за безризиковою ставкою та за умови обмеження коротких продажів ризикових активів. Розроблена статична модель демонструє так звану несвідому схильність уникати збитків, що призводить до нестабільної структури портфелів. Тест моделі за місячними даними показує, що ті інвестори, хто менш схильний до збитків, активно інвестують у безризикові активи, що зумовлює мінімальний ризик у разі збитків. Так, інвестор $з$ коефіцієнтом схильності до ризику 2,25 (3-поміж 10 несиметричних можливих значень у діапазоні від 1 до 10) інвестує в безризиковий актив усі свої кошти. За річними даними, зазначені інвестори більше запозичують за безризиковою ставкою, що в деяких випадках призводить до банкрутства. Для коефіцієнта схильності 2,25 такі інвестори запозичують учетверо більше власних коштів, ризикуючи втратити 99 \% інвестицій. Отже, теорія перспектив має здебільшого нормативний характер. 
Динамічна модель дає кращі результати: інвестори зі схильністю на рівні 2 отримують найбільший прибуток та найвищу статистично значущу додаткову дохідність за альфа-коефіцієнтом Дженсена. Проте негативно на таких інвесторів впливає так званий «ефект пам'яті» або «ефект грошей за будинок» 5 , який передбачає, що попередні успіхи суттєво визначають майбутні рішення. Тобто інвестори, які мали високі прибутки в попередніх операціях, схильні інвестувати у більш ризикові папери в майбутньому.

У сучасній практиці міжнародного портфельного інвестування поведінкові впливи найчастіше виявляють у вигляді так званої схильності до інвестування на місцевих ринках ${ }^{6}$. Саме їй присвячено значну частину наукової, передусім емпіричного спрямування, літератури у сфері міжнародного портфельного інвестування бігевіористського напряму. Сутність цієї поведінкової особливості міжнародних інвесторів у тому, що вони сприймають зарубіжні ринки як щось невідоме, малодосліджене, невизначене. Подібне сприйняття призводить до того, що реальні передумови підвищення ефективності інвестиційних портфелів унаслідок їх міжнародної диверсифікації ігнорують, і такі інвестори віддають перевагу інвестуванню на місцевих ринках. Останні є для інвесторів психологічно близькими, безпечними, зрозумілими, комфортними. Крім того, важливими причинами виникнення такої схильності в сучасній науковій літературі $є$ інституційні бар'єри, податки й транзакційні витрати, необхідність хеджування ризику купівельної спроможності, реальна інформаційна асиметрія тощо.

Ця схильність - одна з найсуттєвіших перешкод на шляху міжнародних портфельних інвестицій. Причому йдеться насамперед про приватних інвесторів і значно меншою мірою - про інституційних. І ось чому. Інституційні інвестори мають професійний штат, який займається портфельним менеджментом. Вони добре обізнані з наявними теоріями та підходами, значно меншою мірою керуються емоціями. Приватні ж інвестори частіше перебувають під впливом ментальних чинників, що інкорпоровані до їхнього попиту на інвестиційні стратегії (портфелі). У такий спосіб вони й стримують інституційних інвесторів від інвестування за кордон. Сучасними науковцями проведено багато теоретичних досліджень та емпіричних тестів зазначеної схильності [38-40].

Останнім часом поведінкові теорії набувають значного поширення, кількість наукових публікацій у цій сфері суттєво зростає. Так, однією з відомих сучасних праць є робота Т. Говарда «Поведінковий портфельний менеджмент: як успішні інвестори регулюють власні емоції та формують кращі портфелі» (2014 р.) [27]. Базуючись на зазначених теоріях, Говард формує власну поведінкову портфельну теорію, а саме

\footnotetext{
${ }^{5}$ House money effect. Наявність цього поведінкового ефекту вперше обгрунтована Р. Талером та Е. Джонсоном [37]. Одне з пояснень такого ефекту в процесі прийняття інвестиційних рішень полягає саме в існуванні зазначеного множинного ментального обліку.

${ }^{6}$ Home bias.
} 
констатує домінування реалізму над раціоналізмом та зазначає, що поведінкова портфельна теорія описує світ, у якому ціни навряд чи відображають фундаментальні характеристики цінних паперів, насправді, вони $є$ результатом дії на ринку емоційних натовпів, які нездатні або не бажають гальмувати свої пристрасті [27, с. 4].

Поведінкова теорія Говарда базується на трьох принципах. По-перше, на ринку є дві групи учасників: емоційні натовпи та поведінкові інвестори. Ціни на ринку визначають саме емоційні натовпи, а тому не відображають внутрішню вартість активів, а відхилення цін $є$ радше правилом, ніж винятком. При цьому події, які стимулюють дії натовпів, можуть мати короткотерміновий характер, а емоції, що виникатимуть унаслідок цього, - довготерміновий. Інвестиційні рішення поведінкових інвесторів є ментально важкими, оскільки передбачають посідання позицій, протилежних позиціям емоційних натовпів, а саме процес поведінкового інвестування неможливий без використання довготермінових стратегій.

По-друге, поведінкові інвестори отримують вищу дохідність порівняно з іншими ${ }^{7}$. Деякі емпіричні дослідження свідчать, що більшість інституційних менеджерів зазвичай отримують дохідність на рівні ринкової чи нижчу за неї, тобто мають нульові або негативні альфакоефіцієнти своїх портфелів. Отже, вони повинні бути поведінковими менеджерами, проте дедалі більше вони залучаються до інституційності; до того ж, чим значніший обсяг портфеля, то ближчі вони у своїх діях до натовпів. Це зумовлено тим, що для залучення нових приватних інвесторів (для збільшення обсягу коштів під управлінням) вони мають задовольняти вимоги емоційних натовпів, стаючи згодом такими самими.

По-третє, інвестиційний ризик - це можливість недоотримання дохідності, тобто теорія не визнає волатильність як реальну міру ризику інвестицій ${ }^{8}$. Більша частина волатильності в іï суто фінансовому розумінні зумовлена саме реакціями натовпів на ту чи іншу інформацію. При цьому мінімальну частку волатильності визначають впливом фундаментальних чинників на рівні ринку та окремих цінних паперів. Сама ж волатильність у підсумку є мірою радше емоцій, ніж інвестиційного ризику. Проблема волатильності в тому, що вона зважає не на кінцевий результат, а переважно на його мінливість. Тому часто на основі волатильності можна отримати портфелі з вищим ризиком та нижчою майбутньою вартістю. Приміром, більш ризикові акції переграють менш ризикові боргові цінні папери у довготерміновому періоді, хоча короткотермінова волатильність перших значно вища. Цей принцип є найскладнішим для інвесторів з огляду його усвідомлення та прийняття. За теорією Говарда, загальну волатильність можна декомпонувати на три складові:

\footnotetext{
7 Зазначене положення є радше не принципом, а припущенням, яке має численні емпіричні підтвердження. Наведено в авторському формулюванні.

${ }^{8}$ У цьому контексті волатильність - це будь-яка традиційна міра ризику: стандартне відхилення, дисперсія, напівдисперсія тощо.
} 
волатильність унаслідок емоційності натовпів; волатильність завдяки бізнес-ризику інвестора (інституційного) та власне фінансова волатильність, яка й має бути урахована за прийняття довготермінових портфельних рішень на основі волатильності [26].

Практичну імплікацію теорії Говарда рекомендовано здійснювати у поєднанні 3 п'ятьма інвестиційними критеріями [41]: інвестування в акції компаній, що платять дивіденди; врахування прогнозних значень коефіцієнта $P / E$ - на рівні як самої компанії, так і за прогнозами незалежних аналітиків; обрання акцій компаній з максимальною заборгованістю; відбір акцій за коефіцієнтом «ціна - продажі»; установлення мінімального порогового значення обсягів продажів. Щодо другого та четвертого критеріїв, то за інших рівних умов пропонують обирати мінімальні значення відповідних показників, що свідчитиме про недооціненість акцій.

У деяких дослідженнях поведінковий портфельний менеджмент називають новою парадигмою [41]. Говард таку назву не вживає, використовуючи інші - гносеологічно менш вимогливі - терміни, такі як концепція [26, с. 44] або підхід [27, с. 7]. Парадигма, на його думку, є більш загальною - це поведінкові фінанси [26, с. 44]. До того ж автор визнає існування в цій сфері двох парадигм: сучасної портфельної теорії та парадигми, запровадженої Гремом і Доддом, назву якій він не дає. У цьому контексті не можна погодитися 3 хронологічним ідентифікатором першої парадигми - iї Говард датує серединою 1970-х років.

Результати проведеного дослідження зведено у таблицю, що характеризує гносеологічне значення найважливіших етапів еволюції бігевіористського напряму інвестиційного менеджменту.

У гносеологічному сенсі поведінкові теорії не є такими, що самостійно дають пояснення рішень міжнародних портфельних інвесторів. Вони радше базуються на інших теоріях та роз'яснюють ті чи інші напрями адаптації портфельних рішень 3 урахуванням поведінкових чинників. Отже, у цьому дослідженні бігевіоризм не віднесено до жодної 3 ідентифікованих парадигм, а розглянуто як загальну міждисциплінарну теорію, яка лише пояснює окремі відхилення рішень інвесторів від тих, що передбачені портфельною (більшою мірою) та вартісною парадигмами. Здебільшого в наукових публікаціях схильність до інвестування на місцевих ринках як головний напрям прояву поведінкових відхилень у процесі міжнародного портфельного інвестування називають «загадкою» ${ }^{9}$. I це тому, що іiі справді досі не вирішено, а результати низки досліджень часто є протилежними.

Отже, існують дві різко відмінні групи поведінкових теорій. Перша - це теорії, що більшою мірою базуються на портфрельній nарадигмі міжнародного інвестування. Теорії другої групи спираються на вартісну парадигму.

\footnotetext{
${ }^{9}$ Home bias puzzle.
} 
Основні етапи еволюції сучасної поведінкової теорії міжнародного портфельного інвестування

\begin{tabular}{|c|c|c|c|c|}
\hline Рік & Автор & Назва & Сутність & Гносеологічне значення \\
\hline 1979 & $\begin{array}{l}\text { Д. Канеман, } \\
\text { А. Тверскі }\end{array}$ & $\begin{array}{l}\text { Теорія } \\
\text { перспектив }\end{array}$ & $\begin{array}{l}\text { Опонування принципам корисності. Відхилення рішень, } \\
\text { які передбачені всіма можливими перспективами. } \\
\text { Недооцінювання єдино можливих перспектив. } \\
\text { Зміна схильності до ризику }\end{array}$ & $\begin{array}{l}\text { Перший еволюційно значущий вплив } \\
\text { на формування поведінкової теорії } \\
\text { міжнародного портфельного інвестування }\end{array}$ \\
\hline 1987 & Л. Лопес & Теорія $S P / A$ & $\begin{array}{l}\text { Вплив на рішення індивідів таких ключових емоцій } \\
\text { та відчуттів, як безпека, потенціал і прагнення. } \\
\text { Готовність ризикувати визначається страхом } \\
\text { (завищення ймовірностей гірших результатів) } \\
\text { та надією (завищення ймовірностей кращих результатів) }\end{array}$ & $\begin{array}{l}\text { Перехідна ланка між загальною поведінко- } \\
\text { вою теорією та бігевіоризмом у портфель- } \\
\text { ному контексті. Відповідність положенням } \\
\text { портфельної парадигми міжнародного } \\
\text { інвестування в частині принципу } \\
\text { максимальної визначеності }\end{array}$ \\
\hline 2000 & $\begin{array}{l}\text { Г. Шефрін, } \\
\text { М. Стетмен }\end{array}$ & $\begin{array}{l}\text { Поведінкова } \\
\text { теорія } \\
\text { портфеля }\end{array}$ & $\begin{array}{l}\text { Інвестиційні рішення приймаються на основі множинного } \\
\text { ментального обліку. Портфель може розглядатися як ціліс- } \\
\text { ність чи сукупність окремих ментальних рахунків індивіда } \\
\text { (окремі дизагреговані прошарки в свідомості інвестора). } \\
\text { Урахування поряд із традиційними факторами інвестицій- } \\
\text { них рішень (ризику й дохідності) ще й ступеня страху, надії, } \\
\text { прагнення, сили страху щодо надії та сили прагнення щодо } \\
\text { надії та страху }\end{array}$ & $\begin{array}{l}\text { Базується на двох попередніх теоріях, } \\
\text { проте чітко сформульована у } \\
\text { портфельному контексті }\end{array}$ \\
\hline 2014 & Т. Говард & $\begin{array}{l}\text { Теорія } \\
\text { поведінкового } \\
\text { портфельного } \\
\text { менеджменту } \\
\text { або теорія } \\
\text { натовпів }\end{array}$ & $\begin{array}{l}\text { Ринкові ціни є наслідком дії на ринку емоційних натовпів, } \\
\text { які нездатні або не бажають гальмувати свої емоції. } \\
\text { Інвестиційні рішення поведінкових інвесторів } \\
\text { є ментально важкими, оскільки мають бути протилежними } \\
\text { діям натовпів. Вони повинні мати довготерміновий характер. } \\
\text { У підсумку поведінкові інвестори отримують вищу } \\
\text { дохідність порівняно з іншими }\end{array}$ & $\begin{array}{l}\text { Формально не базується на попередніх } \\
\text { теоріях, натомість } є \text { новим поглядом } \\
\text { на прийняття портфельних рішень. } \\
\text { Заперечує як портфельній, так і вартісній } \\
\text { парадигмі міжнародного портфельного } \\
\text { інвестування. Дає конкретні рекомендації } \\
\text { щодо формування портфелів }\end{array}$ \\
\hline
\end{tabular}

Джерело: зведено автором. 
Серед досліджених теорій лише теорію Говарда можна віднести до другої групи. Сама ж концепція поведінкового портфельного менеджменту могла б гіпотетично стати парадигмою, якби не використовувала напрацювання наявних парадигм, а запропонувала принципово нову методологію постановки проблем та їх вирішення. Наразі така іiі гносеологічна ідентифікація є неможливою.

Висновки. Поведінкова теорія посідає особливе місце в сучасній теорії міжнародного портфельного інвестування, надзвичайно активно розвивається, формує міждисциплінарний характер останньої. Її появі передували поведінкові теорії більш загального спрямування. Теорія перспектив (1979р.) опонує не якійсь парадигмі конкретно, а теорії корисності як такій. Вона пропонує інший спосіб прийняття рішень в умовах ризику - на основі таких поведінкових ефектів, як ігнорування та визначеності. Теорія $S P / A$ (1987 р.) також розглядає процес прийняття рішень в умовах невизначеності та оперує такими важливими людськими відчуттями, як безпека, потенціал і прагнення. Поведінкова теорія портфельного вибору, що сформульована у 2000 р., базується на двох зазначених теоріях та інкорпорує ідею множинного ментального обліку.

Важливим доробком у цій галузі $є$ теорія поведінкового портфельного менеджменту Т. Говарда, розроблена в 2014 р. За цією теорією, основним чинником зміни ціни на ринку є емоції натовпів, які нездатні або не бажають відпускати гальма своїх емоцій. Поведінкові інвестори натомість повинні керуватися фундаментальними характеристиками цінних паперів і можуть досягти успіху, інвестуючи у протилежному від натовпів напрямі. Портфельний менеджмент повинен мати довготерміновий характер.

Попри свою важливість, позитивний характер і значне поширення, бігевіоризм у гносеологічному плані не можна ідентифікувати як парадигму, проте такі підходи трапляються. Поведінкові теорії не дають пояснення рішенням міжнародних інвесторів самостійно, вони базуються на положеннях чинних парадигм міжнародного інвестування портфельної та вартісної. Тому бігевіоризм не є самодостатнім.

Враховуючи, що в процесі міжнародного портфельного інвестування беруть участь інвестори - резиденти багатьох країн, які мають різну культуру, ментальність, традиції та навіть світогляд, бігевіоризм багаторазово довів, що він $є$ надзвичайно релевантним саме для пояснення міжнародних інвестиційних процесів у крос-культурному середовищі, хоча поведінкова теорія номінально не спрямована саме на міжнародні процеси, а є універсальною, з погляду застосування в різних умовах, у тому числі й на локальних ринках.

У сучасній практиці міжнародного портфельного інвестування поведінкові впливи знаходять прояв найчастіше у вигляді так званої схильності до інвестування на місцевих ринках. Стримування міжнародного портфельного інвестування відбувається внаслідок негативного сприйняття інвесторами зарубіжних ринків як чогось невідомого, 
небезпечного, нестабільного. Натомість вони більше інвестують на місцевих ринках - ближчих та зрозуміліших. У такий спосіб інвестори почуваються безпечніше, їхні емоції перебувають у спокої, а самі вони у психологічній зоні комфорту. Така схильність є однією з найсуттєвіших перешкод на шляху міжнародних портфельних інвестицій. Проте останнім часом кількість перешкод знизилася та продовжує знижуватися, у тому числі через зростання рівня обізнаності інвесторів.

\section{СПИСОК ВИКОРИСТАНИХ ДЖЕРЕ}

1. Markowitz H. M. Portfolio Selection. The Journal of Finance. 1952. Vol. 7. № 1. P. 77-91.

2. Markowitz H. M. Portfolio Selection: Efficient Diversification of Investments. New York: John Wiley \& Sons, Inc.; London: Chapman \& Hall, Ltd.; Cowles Foundation for Research in Economics at Yale University. 1959. 344 p.

3. Roy A. D. Safety First and the Holding of Assets. Econometrica. 1952. Vol. 20. № 3. P. 431-449.

4. Sharpe W. F. Capital Asset Prices: A Theory of Market Equilibrium under Conditions of Risk. The Journal of Finance. 1964. Vol. 19. № 3. P. 425-442.

5. Sharpe W. F. Expected Utility Asset Allocation. Financial Analysts Journal. 2007. Vol. 63. № 5. P. 18-30.

6. Merton R. C. An Analytic Derivation of the Efficient Portfolio Frontier. The Journal of Financial and Quantitative Analysis. 1972. Vol. 7. № 4. P. 1851-1872.

7. Solnik B. H. Why Not Diversify Internationally Rather than Domestically? Financial Analysts Journal. 1974. Vol. 30. № 4. P. 48-54.

8. Longin F., Solnik B. Extreme Correlation of International Equity Markets. The Journal of Finance. 2001. Vol. 56. № 2. P. 649-676.

9. Rom B. A., Ferguson K. W. Post-Modern Portfolio Theory Comes of Age. The Journal of Investing. 1993. Vol. 2. № 4. P. 27-33.

10. Chen J. M. Postmodern Portfolio Theory: Navigating Abnormal Markets and Investor Behavior (Quantitative Perspectives on Behavioral Economics and Finance). Palgrave Macmillan, 2016. 339 p.

11. Todoni M. A Post-Modern Portfolio Management Approach on CEE Markets. Procedia Economics and Finance. 2015. Vol. 32. P. 1362-1376.

12. Eun C. S., Resnick B. G. International Diversification of Investment Portfolios: U.S. and Japanese Perspectives. Management Science. 1994. Vol. 40. № 1. P. 140-161.

13. McDowell S. The Benefits of International Diversification: Re-examining the Effect of Market Allocation Constraints. The North American Journal of Economics and Finance. 2017. Vol. 41. P. 190-203.

14. Fletcher J. An Empirical Examination of the Diversification Benefits of U.K. International Equity Closed-End Funds. International Review of Financial Analysis. 2018. Vol. 55. P. 23-34.

15. Graham B., Dodd D. L. Security Analysis. New York, London: Whittlesey House, McGraw-Hill Book Company, Inc. 1934. 725 p.

16. Tinbergen J. The Dynamics of Share-Price Formation. The Review of Economic Statistics. 1939. Vol. 21. № 4. P. 153-160.

17. Fama E. F. French K. R. Size, Value, and Momentum in International Stock Returns. Journal of Financial Economics. 2012. Vol. 105. № 3. P. 457-472.

18. Fama E. F., French K. R. A Five-Factor Asset Pricing Model. Journal of Financial Economics. 2015. Vol. 116. № 1. P. 1-22.

19. Fama E. F., French K. R. Common Risk Factors in the Returns on Stocks and Bonds. Journal of Financial Economics. 1993. Vol. 33. № 1. P. 3-56. 
20. Fama E. F., French K. R. International Tests of a Five-Factor Asset Pricing Model. The Journal of Financial Economics. 2017. Vol. 123. № 3. P. 441-463.

21. Fama E. F., French K. R. Value versus Growth: The International Evidence. The Journal of Finance. 1998. Vol. 53. № 6. P. 1975-1999.

22. Hanauer M. X., Linhart M. Size, Value, and Momentum in Emerging Market Stock Returns: Integrated or Segmented Pricing. Asia-Pacific Journal of Financial Studies. 2015. Vol. 44. № 2. P. 175-214.

23. Cakici N., Fabozzi F. J., Tan S. Size, Value, and Momentum in Emerging Market Stock Returns. Emerging Markets Review. 2013. Vol. 16. № 3. P. 46-65.

24. Asness C., Moskowitz T. J., Pedersen L. Value and Momentum Everywhere. The Journal of Finance. 2013. Vol. 68. № 3. P. 929-985.

25. Shefrin H., Statman M. Behavioral Portfolio Theory. The Journal of Financial and Quantitative Analysis. 2000. Vol. 35. № 2. P. 127-151.

26. Howard C. T. Behavioral Portfolio Management. C. Thomas Howard. Investments \& Wealth Monitor. 2014. March-April. P. 44-51.

27. Howard C. T. Behavioral Portfolio Management: How Successful Investors Master Their Emotions and Build Superior Portfolios. Harriman House Ltd. 2014. 324 p.

28. Bi J., Jin H., Meng Q. Behavioral Mean-Variance Portfolio Selection. European Journal of Operational Research. 2018. Vol. 271. № 2. P. 644-663.

29. Lou Y. On the Investment Direction of a Behavioral Portfolio Choice Model. Operations Research Letters. 2019. Vol. 47. № 4. P. 270-273.

30. Oehler A., Wendt S., Horn M. Are Investors Really Home-Biased When Investing at Home? Research in International Business and Finance. 2017. Vol. 40. № 3. P. 52-60.

31. Mukherjee R., Paul S., Shankar S. Equity Home Bias - A Global Perspective from the Shrunk Frontier. Economic Analysis and Policy. 2018. Vol. 57. № 3. P. 9-22.

32. Geranio M., Lazzari V. Stress Testing the Equity Home Bias: A Turnover Analysis of Eurozone Markets. Journal of International Money and Finance. 2019. Vol. 97. № 3. P. 70-85.

33. Kahneman D., Tversky A. Prospect Theory: An Analysis of Decision under Risk. Econometrica. 1979. Vol. 47. № 2. P. 263-292.

34. Lopes L. L. Between Hope and Fear: The Psychology of Risk. Advances in Experimental Social Psychology. 1987. Vol. 20. № 2. P. 255-295.

35. Pfiffelmann M., Roger T., Bourachnikova O. When Behavioral Portfolio Theory Meets Markowitz Theory. Economic Modelling. 2016. Vol. 53. № 3. P. 419-435.

36. Best M. J., Grauer R. R. Prospect Theory and Portfolio Selection. Journal of Behavioral and Experimental Finance. 2016. Vol. 11. P. 13-17.

37. Thaler R. H., Johnson E. J. Gambling with the House Money and Trying to Break Even: The Effects of Prior Outcomes on Risky Choice. Management Science. 1990. Vol. 36. № 6. P. 643-660.

38. Daly K., Vo X. V. The Determinants of Home Bias Puzzle in Equity Portfolio Investment in Australia. International Review of Financial Analysis. 2013. Vol. 27. P. 34-42.

39. Mishra A. V. Measures of Equity Home Bias Puzzle. Journal of Empirical Finance. 2015. Vol. 34. P. 293-312.

40. Mukherjee R., Paul S., Shankar S. Equity Home Bias - A Global Perspective from the Shrunk Frontier. Economic Analysis and Policy. 2018. Vol. 57. P. 9-21.

41. Jaye N. The Next Paradigm. CFA Institute Magazine. 2014. Vol. 25. № 5. P. 28-31.

Стаття надійшла до редакиії 07.10.2019. theory.

Dziuba P. Behaviorism: evolution and place in international portfolio investing

Background. The existing theory of international portfolio has the complicated gnoceological structure. It is developing on the basis of two existing paradigms and demonstrating more and more interdisciplinary features. Traditional approaches to 
international portfolio investing rest upon rational behavior of investing individuals whereas this assumption is often not valid in real life. Behavioral theories focus on specific behavioral deviations and biases of investment decisions and can boast frequent empirical testing.

The aim of the article is to determine the place of behavioral portfolio theory in the modern knowledge system of international portfolio investing, to identify the main directions of its relationship with other components of existing knowledge based on the study of its basic features and shortcomings.

Materials and methods. The study grounds on generally accepted scientific methods of research such as analysis and synthesis, abstraction, historical method and systemic approach as well as on specific methods such as logical and graphical modelling etc. The literature and material used include scientific publications and monographs of leading scientists in the field of financial theory, international portfolio investing and behaviorism.

Results. The emergence of behavioral portfolio theory was preceded by theories of more general direction. The prospect theory (1979) contradicts the utility approach. It suggests another method of risk-acceptance decision that is based on such behavioral effects as eliminating and certainty. The SP/A (1987) theory operates the following important people feelings such as security, potential and aspiration. The behavioral portfolio theory was formulated in 2000 and is based on the idea of multiple mental accounting. T. Howard theory of behavioral portfolio management (2014) is of scientific importance. It implies that the main factor of changes in market prices is represented by the emotions of crowds that are not able or do not want to release the brakes of their emotions. Behavioral investors should instead be guided by fundamental characteristics of securities and can achieve success via investing in the direction opposite to the crowds.

Conclusion. Behavioral theory of international portfolio investing is extremely significant, positive and widely spread though it cannot be identified as a paradigm in gnoceological understanding of portfolio investing. Behavioral theories do not explain the decisions of international investors - they only ground on methodology of existing portfolio and value investing paradigms. However, behavioral theories are especially relevant for international portfolio investing since this process includes investors of different countries, cultures, mentality, outlooks, traditions etc. and imply cross-cultural environment.

Keywords: behavioral theory, international portfolio investing, home bias, prospect theory, theory of behavioral portfolio management.

\section{REFERENCES}

1. Markowitz, H. M. (1952). Portfolio Selection. The Journal of Finance. (Vol. 7), 1, 77-91 [in English].

2. Markowitz, H. M. (1959). Portfolio Selection: Efficient Diversification of Investments. New York: John Wiley \& Sons, Inc.; London: Chapman \& Hall, Ltd.; Cowles Foundation for Research in Economics at Yale University [in English].

3. Roy, A. D. (1952). Safety First and the Holding of Assets. Econometrica. (Vol. 20), 3, 431-449 [in English].

4. Sharpe, W. F. (1964). Capital Asset Prices: A Theory of Market Equilibrium under Conditions of Risk. The Journal of Finance. (Vol. 19), 3, 425-442 [in English].

5. Sharpe, W. F. (2007). Expected Utility Asset Allocation. Financial Analysts Journal. (Vol. 63), 5, 18-30 [in English].

6. Merton, R. C. (1972). An Analytic Derivation of the Efficient Portfolio Frontier / Robert C. Merton. The Journal of Financial and Quantitative Analysis. (Vol. 7), 4, 1851-1872 [in English].

7. Solnik, B. H. (1974). Why Not Diversify Internationally Rather than Domestically? Financial Analysts Journal. (Vol. 30), 4, 48-54 [in English].

8. Longin, F., \& Solnik, B. (2001). Extreme Correlation of International Equity Markets. The Journal of Finance. (Vol. 56), 2, 649-676 [in English]. 
9. Rom, B. A., \& Ferguson, K. W. (1993). Post-Modern Portfolio Theory Comes of Age. The Journal of Investing. (Vol. 2), 4, 27-33 [in English].

10. Chen, J. M. (2016). Postmodern Portfolio Theory: Navigating Abnormal Markets and Investor Behavior (Quantitative Perspectives on Behavioral Economics and Finance). Palgrave Macmillan [in English].

11. Todoni, M. (2015). A Post-Modern Portfolio Management Approach on CEE Markets. Procedia Economics and Finance. (Vol. 32), (pp. 1362-1376) [in English].

12. Eun, C. S., \& Resnick, B. G. (1994). International Diversification of Investment Portfolios: U.S. and Japanese Perspectives. Management Science. (Vol. 40), 1, 140-161 [in English].

13. McDowell, S. (2017). The Benefits of International Diversification: Re-examining the Effect of Market Allocation Constraints. The North American Journal of Economics and Finance. (Vol. 41), (pp. 190-203) [in English].

14. Fletcher, J. (2018). An Empirical Examination of the Diversification Benefits of U.K. International Equity Closed-End Funds. International Review of Financial Analysis. (Vol. 55), (pp. 23-34) [in English].

15. Graham, B., \& Dodd, D. L. (1934). Security Analysis. New York, London: Whittlesey House, McGraw-Hill Book Company, Inc. [in English].

16. Tinbergen, J. (1939). The Dynamics of Share-Price Formation. The Review of Economic Statistics. (Vol. 21), 4, 153-160 [in English].

17. Fama, E. F., \& French, K. R. (2012). Size, Value, and Momentum in International Stock Returns. Journal of Financial Economics. (Vol. 105), 3, 457-472 [in English].

18. Fama, E. F., \& French, K. R. (2015). A Five-Factor Asset Pricing Model. Journal of Financial Economics. (Vol. 116), 1, 1-22 [in English].

19. Fama, E. F., \& French, K. R. (1993). Common Risk Factors in the Returns on Stocks and Bonds. Journal of Financial Economics. (Vol. 33), 1, 3-56 [in English].

20. Fama, E. F., \& French, K. R. (2017). International Tests of a Five-Factor Asset Pricing Model. The Journal of Financial Economics. (Vol. 123), 3, 441-463 [in English].

21. Fama, E. F., \& French, K. R. (1998). Value versus Growth: The International Evidence. The Journal of Finance. (Vol. 53), 6, 1975-1999 [in English].

22. Hanauer, M. X., \& Linhart, M. (2015). Size, Value, and Momentum in Emerging Market Stock Returns: Integrated or Segmented Pricing. Asia-Pacific Journal of Financial Studies. (Vol. 44), 2, 175-214 [in English].

23. Cakici, N., Fabozzi, F. J., \& Tan, S. (2013). Size, Value, and Momentum in Emerging Market Stock Returns. Emerging Markets Review. (Vol. 16), 3, 46-65 [in English].

24. Asness, C., Moskowitz, T. J., \& Pedersen, L. (2013). Value and Momentum Everywhere. The Journal of Finance. (Vol. 68), 3, 929-985 [in English].

25. Shefrin, H., \& Statman, M. (2000). Behavioral Portfolio Theory. The Journal of Financial and Quantitative Analysis. (Vol. 35), 2, 127-151 [in English].

26. Howard, C. T. (2014). Behavioral Portfolio Management. C. Thomas Howard. Investments \& Wealth Monitor. March-April. (pp. 44-51) [in English].

27. Howard, C. T. (2014). Behavioral Portfolio Management: How Successful Investors Master Their Emotions and Build Superior Portfolios. Harriman House Ltd [in English].

28. Bi, J., Jin H., \& Meng, Q. (2018). Behavioral Mean-Variance Portfolio Selection. European Journal of Operational Research. (Vol. 271), 2, 644-663 [in English].

29. Lou, Y. (2019). On the Investment Direction of a Behavioral Portfolio Choice Model. Operations Research Letters. (Vol. 47), 4, 270-273 [in English].

30. Oehler, A., Wendt, S., \& Horn, M. (2017). Are Investors Really Home-Biased When Investing at Home? Research in International Business and Finance. (Vol. 40), 3, 52-60 [in English].

31. Mukherjee, R., Paul, S., \& Shankar, S. (2018). Equity Home Bias - A Global Perspective from the Shrunk Frontier. Economic Analysis and Policy. (Vol. 57), 3, 9-22 [in English]. 
32. Geranio, M., \& Lazzari, V. (2019). Stress Testing the Equity Home Bias: A Turnover Analysis of Eurozone Markets. Journal of International Money and Finance. (Vol. 97), 3, 70-85 [in English].

33. Kahneman, D., \& Tversky, A. (1979). Prospect Theory: An Analysis of Decision under Risk. Econometrica. (Vol. 47), 2, 263-292 [in English].

34. Lopes, L. L. (1987). Between Hope and Fear: The Psychology of Risk. Advances in Experimental Social Psychology. (Vol. 20), 2, 255-295 [in English].

35. Pfiffelmann, M., Roger, T., \& Bourachnikova, O. (2016). When Behavioral Portfolio Theory Meets Markowitz Theory. Economic Modelling. (Vol. 53), 3, 419-435 [in English].

36. Best, M. J., \& Grauer, R. R. (2016). Prospect Theory and Portfolio Selection. Journal of Behavioral and Experimental Finance. (Vol. 11), (pp. 13-17) [in English].

37. Thaler, R. H., \& Johnson, E. J. (1990). Gambling with the House Money and Trying to Break Even: The Effects of Prior Outcomes on Risky Choice. Management Science. (Vol. 36), 6, 643-660 [in English].

38. Daly, K., \& Vo, X. V. (2013). The Determinants of Home Bias Puzzle in Equity Portfolio Investment in Australia. International Review of Financial Analysis. (Vol. 27), (pp. 34-42) [in English].

39. Mishra, A. V. (2015). Measures of Equity Home Bias Puzzle. Journal of Empirical Finance. (Vol. 34), (pp. 293-312) [in English].

40. Mukherjee, R., Paul, S., \& Shankar, S. (2018). Equity Home Bias - A Global Perspective from the Shrunk Frontier. Economic Analysis and Policy. (Vol. 57), (pp. 9-21) [in English].

41. Jaye, N. (2014). The Next Paradigm. CFA Institute Magazine. (Vol. 25), 5, 28-31 [in English]. 